\title{
KEMAMPUAN ALAT PENYARING UDARA DENGAN MEDIA PELEPAH PISANG DAN ZEOLITE UNTUK MENURUNKAN KADAR KARBON MONOKSIDA (CO) DI UDARA St.Mu tamirah ${ }^{1}$ dan Baharuddin Sunu ${ }^{2}$ \\ ${ }^{1.2}$ Politeknik Kesehatan Muhammadiyah Makassar \\ stmutamirah@gmail.com
}

\begin{abstract}
The city of Makassar is one of the cities with usually increased population densities. The rapid growth of the population of course followed by increasing community needs of transportation which is indicated by the increased emissions of a motor vehicle like carbon monoxide. Carbon monoxide passing through the air quality standard will harm human health. The aim of this study was to knowability air filter instrument media by membrane Cellulosa acetate fiber and zeolite to reduce carbon monoxide (CO) levels in the air. The methods of this study were an experiment. The population of this study was all site Air pollution produces to the transportation process of gas emission vehicles taken in around traffic light. The technical sampling was NonRandomized Pretest-Postest Control Design that is two categories of the user object. The first category was the trial unite to measure carbon monoxide emission before past filter instrument and the second category is measure control after past filter instruments. The conclusion of the study resulted in measure carbon monoxide emission before past media filter by membrane acetate fiber and zeolite is $60 \mathrm{ppm}$ to the first site and $700 \mathrm{ppm}$ to the second site. Result of carbon monoxide declines the use of air filter instrument is $66,6 \%$ to the first site and $84 \%$ to the second site. Causes of differences in measurement result at both points are placement object of an instrument, the first site at the traffic light fly over while the second site at the vehicle exhaust.
\end{abstract}

Keywords : Air filter, Membran selulosa asetat, Zeolite, Carbon monoxide

\section{ABSTRAK}

Kota Makassar merupakan salah satu kota dengan kepadatan penduduk yang terus menerus mengalami peningkatan pesatnya pertambahan penduduk tentu dibarengi dengan peningkatan kebutuhan masyarakat dibidang transportasi yang diindikasikan dengan meningkatnya emisi kendaraan bermotor seperti gas karbon monoksida (CO). Karbon monoksida yang melewati baku mutu udara akan membahayakan kesehatan Manusia.Tujuan umum penelitian ini untuk mengetahui kemampuan alat penyaring udara dengan media pelepah pisang dan zeolite untuk menurunkan kadar karbon monoksida (CO) di udara. Metode penelitian yang digunakan adalah metode eksperimen. Populasi dalam penelitian ini adalah semua titik atau lokasi yang menghasilkan polutan udara (CO) pada proses transportasi gas buang kendaraan yang diambil di sekitaran lampu merah. Tehnik pengambilan sampel adalah rancangan Non Randomized Pretest-postest Control Design. Hasil penelitian dapat disimpulkan bahwa : Kadar karbon monoksida (CO) sebelum melalui media penyaring pelepah pisang dan zeolite adalah $60 \mathrm{ppm}$ pada titik pertama dan 700 ppm pada titik kedua. Hasil penurunan kadar CO dengan menggunakan alat penyaring udara pelapah pisang dan zeolite adalah $66,6 \%$ pada titik 1 dan $84 \%$ pada titik 2 . Hal yang menyebabkan terjadinya perbedaan hasil pengukuran dikedua titik ini adalah objek penempatan alat yang berbeda, pada titik 1 pengukuran dilakukan jauh dari sumber CO (kendaraan) dan pada titik 2 pengukuran dilakukan langsung di knalpot kendaraan bermotor.

Kata Kunci : Penyaring udara, Pelepah pisang, Zeolite, karbon monoksida

\section{Pendahuluan}

Udara mempunyai arti yang sangat penting di dalam kehidupan mahluk hidup dan keberadaan benda-benda lainnya. Sehingga udara merupakan sumber daya alam yang harus dilindungi untuk hidup, kehidupan manusia dan mahluk hidup lainnya. Hal ini berarti bahwa pemanfaatannya harus dilakukan secara bijaksana dengan memperhitungkan kepentingan generasi sekarang dan yang akan datang. Untuk mendapatkan udara sesuai dengan tingkat kualitas yang diinginkan maka pengendalian pencemaran udara menjadi sangat penting untuk dilakukan. Udara merupakan media lingkungan yang perlu menjadi perhatian dari sasaran dan kawasan tersebut di atas. Hal ini telah pula menjadi kebijakan Pembangunan Kesehatan Indonesia Sehat tahun 2010 dimana program pengendalian pencemaran udara merupakan salah satu dari sepuluh program unggulan (Kemenkes RI No.1407/MENKES/SK/XI/2002).

Pencemaran udara merupakan suatu kondisi dimana kehadiran satu atau lebih subtansi kimia, fisik atau biologi di atmosfer dalam jumlah yang mebahayakan. Berbahaya bagi kesehatan manusia. Pencemaran dengan kata lain didefenisikan sebagai perusak terhadap kualitas udara. Kerusakan kualitas ini di sebabkan oleh berbagai sumber yang merusak kesehatan mahluk hidup maupun benda mati. Polusi udara hanya merupakan salah satu dari jenis pencemaran lingkungan hidup.udara dapat bersumber dari berbagai macam, antara lain : asap kendaraan bermotor, asap pabrik, limbah industri, limbah rumah tangga dan lain-lain (Anonim, 2013).

Penyebab pencemaran udara di Indonesia $70 \%$ merupakan hasil dari emisi kendaraan bermotor, kendaraan bermotor mengeluarkan zatzat berbahaya yang dapat menimbulkan dampak negatif, baik terhadap kesehatan manusia maupun terhadap lingkungan. Zat berbahaya tersebut seperti timbal/timah hitam $(\mathrm{Pb})$, Suspended particulate matter (SPM), oksida Nitrogen (NOx), Hidrokarbon (HC), karbon monooksida (CO), dan oksida fotokimia (Ox), (Kemenkes RI No.289/Menkes/SK/III/2003).

Indonesia adalah salah satu negara yang 
Jurnal Sulolipu : Media Komunikasi Sivitas Akademika dan Masyarakat

Vol. 19 No.1 2019

e-issn : 2622-6960, p-issn : 0854-624X

mempunyai resiko terkena dampak EL-NINO dan LA-NINA. Dampak dari EL-NINO menimbulkan perubahan iklim, antara lain musim panas yang berkepanjangan sehingga menimbulkan kekeringan dan pada akhirnya menjadi salah satu faktor terjadinya kebakaran hutan. Dampak dari kebakaran hutan terhadap lingkungan sangan luas antara lain kerusakan ekologi, menurunnya keanekaragaman sumber daya hayati dan ekosistemnya, serta penurunan kualitas udara. Berbagai pencemaran udara yang ditimbulkan akibat kebakaran hutan, misalnya : debu dengan ukuran partikel kecil (PM10 dan PM2,5), Gas SOx, NOx,COx dan lain-lain. Dengan melihat prediksi serta asumsi pola iklim sebagai dampak dari ELNINO maka perlu dilakukan langkah-langkah antisipasi sehingga dapat meminimalkan dampak kesehatan akibat kebakaran hutan (Kemenkes RI No.289/Menkes/SK/III/2003).

Pencemaran udara pada saat ini sudah mencapai tingkat mengkhawatirkan, karena didukung oleh perkembangan dunia industri, banyaknya manusia yang tinggal didunia ini dapat menjadikan pencemaran udara semakin meningkat. Terlebih - lebih di Indonesia, pencemaran udara di Indonesia sudah sangat mengkhawatirkan, pencemaran asap kendaraan bermotor menjadi sumber yang paling utama pencemaran udara di Indonesia, jumlah kendaraan bermotor yang tidak seimbang dengan jumlah pepohonan yang ada di Indonesia mejadi salah satu penghambat terjadinya pertukaran udara di Indonesia, sifat konsumtif masyarakat Indonesia menjadikan jumlah kendaraan bermotor di Indonesia menjadi banyak dan dapat dipastikan mejadikan hal tersebut sangat berpengaruh terhadap tingginya pencemaran udara di Indonesia. Illegal logging menjadi salah satu hal yang sangat perngaruh terhadap pencemaran udara di Indonesia, kasus illegal logging yang meningkat dan juga kurangnya lahan diperkotaan menjadi sumber utama masalah udara di Indonesia. Efek dari pencemaran udara juga sudah dapat dirasakan pada saat ini, banyaknya penyakit yang bersumber dari udara, peningkatan jumlah pengidap ispa dan juga bertambahnya jumlah orang yang tua sebelum waktunya menjadi efek negatif dari pencemaran udara (Info Kemenkes RI, 2015).

Asap kendaraan merupakan sumber utama bagi karbon monoksida di berbagai perkotaan. Data mengungkapkan bahwa $60 \%$ pencemaran udara di Jakarta disebabkan karena benda bergerak atau transportasi umum yang berbahan bakar solar terutama berasal dari Angkutan Umum . Formasi CO merupakan fungsi dari rasio kebutuhan udara dan bahan bakar dalam proses pembakaran di dalam ruang bakar mesin diesel. Percampuran yang baik antara udara dan bahan bakar terutama yang terjadi pada mesin-mesin yang menggunakan Turbocharge merupakan salah satu strategi untuk meminimalkan emisi CO. Karbon monoksida yang meningkat diberbagai perkotaan dapat mengakibatkan turunnya berat janin dan meningkatkan jumlah kematian bayi serta kerusakan otak. Karena itu strategi penurunan kadar karbon monoksida akan tergantung pada pengendalian emisi seperti pengggunaan bahan katalis yang mengubah bahan karbon monoksida menjadi karbon dioksida dan penggunaan bahan bakar terbarukan yang rendah polusi bagi kendaraan bermotor (KEP107/KABAPEDAL/II/1997).

Karbon Monoksida (CO) adalah gas yang bersifat membunuh makhluk hidup termasuk manusia. Zat gas $\mathrm{CO}$ ini akan mengganggu pengikatan oksigen pada darah karena CO lebih mudah terikat oleh darah dibandingkan dengan oksigen dan gas-gas lainnya. Pada kasus darah yang tercemar karbon monoksida dalam kadar $70 \%$ hingga $80 \%$ dapat menyebabkan kematian (Kemenkes RI No. 1407, 2002).

Pada saat ini telah ada alat yang dapat memantau kualitas udara di suatu tempat, alat yang dapat memantau kualitas udara tersebut dinamakan papan Indeks Standar Pencemar Udara atau yang disingkat (ISPU). Papan ISPU merupakan laporan kualitas udara kepada masyarakat untuk menerangkan seberapa bersih atau tercemarnya udara dan bagaimana dampaknya terhadap kesehatan setelah menghirup udara tersebut selama beberapa jam atau hari. Papan ISPU secara kontinyu memberi informasi kepada masyarakat mengenai tingkat kelayakan udara di suatu daerah (Info Kemenkes $\mathrm{RI}, 2015)$.

Pelepah pisang mungkin hanya sekedar jadi barang tidak berguna bagi sebagaian besar orang. Tapi lain hal yang sama tidak terjadi di tangan Meitri widya pangestika. Tak tanggungtanggung, lewat inovasinya, pelepah dan tangkai daun pisang dimanfaatkannya untuk menyaring udara kotor penuh karbon monoksida. Dari hasil penelitian tersebut pelepah yang dikeringkan dan diproses karbonasi hasilnya di buat jadi filter, apabila di pasang dimotor, dia bisa menyaring karbon monooksida hingga $76 \%$, dan apabila dibuat masker efek filtrasinya $94 \%$ (Meitri Widya, 2014).

Udara panas disebuah ruangan biasanya disiasati dengan pemasangan penyejuk udara atau kipas angin. Namun, ternyata batang pisang juga memiliki fungsi yang serupa. Tiga orang siswa yang mengoptimalkan fungsi batang pisang menjadi penyejuk udara. Tiga siswa ini bersekolah di SMP Negeri 8 Yogyakarta yang terdiri dari Finandy Arkhan Ramadhan, Rafie Amandio fauzan, dan Ridwansyah Yahya dan memiliki ide 
Jurnal Sulolipu : Media Komunikasi Sivitas Akademika dan Masyarakat

Vol. 19 No.1 2019

e-issn : 2622-6960, p-issn : 0854-624X

untuk menciptakan penyejuk udara yang ramah lingkungan, dan dasar keprihatinan masih banyaknya penyejuk udara buatan pabrik yang menggunakan freon. Salah seorang anggota tim mengungkapkan rongga batang pisang memiliki banyak kandungan air, dan diyakini memberikan kelembaban yang cukup untuk digunakan sebagai penyejuk udara di sebuah ruangan. Percobaan awal, batang pisang basah hanya mereka gantung menggunkan hanger pakaian. Pada alat yang mereka buat ini, batang pisang yang basah kemudian di susun sedemikian rupa pada sebuah alat rakitan berbahan akrilik yang dibentuk seperti wadah kotak (Harianjogja.com, 2016)

Pada tahun 1840 Damour seorang peneliti mineral mengemukakan bahwa mineral zeolit mempunyai kemampuan sebagai absorben.ia mengamati bahwa mineral zeolite dapat terdehidrasi secara reversibel tanpa menunjukkan adanya perubahan fungsi morfologi. Kemudian pengamatan berlanjut pada kemampuan zeolite untuk melakukan pertukaran ion oleh Eichorn pada tahun 1858. Setelah itu menyusul penemuan oleh McBain pada tahun 1931 yang melakukan uji coba pemanasan mineral zeolit (aktivasi dan mendapatkan zeolit mampu menyerap molekulmolekul gas dengan ukuran partikel tertentu) ( Dalam M.Ali Akbar, 2010)

Kota Makassar sebagai gerbang Kawasan Timur Indonesia adalah salah satu kota dengan kepadatan penduduk yang terus mengalami peningkatan. Pesatnya pertambahan penduduk kota Makassar ini tentunya dibarengi dengan peningkatan kebutuhan masyarakat diberbagai bidang misalnya dalam bidang transportasi yang diindikasikan dengan meningkatnya emisi kendaraan bermotor. Total keseluruhan kendaraan bermotor yang beroperasi di wilayah makassar untuk tahun 2016 mencapai 1.425.151 unit atau bertambah 87.009 unit dibandingkan tahun 2015. Pada tahun 2014 jumlah kendaraan bermotor di kota Makassar baru berkisar 172.395 unit. jika dirata-ratakan, pertumbuhan kendaraan bermotor di Makassar berkisar 7\% setiap tahunnya (Ade Firmansyah, 2017)

Jika hal ini terus berlanjut tanpa ada upaya perbaikan kualitas lingkungan di Kota Makassar maka akan berimbas pada meningkatnya pencemaran lingkungan, khususnya pada pencemaran udara Zat-zat pencemar udara yang paling sering dijumpai di lingkungan perkotaan khususnya yang diakibatkan oleh alat transportasi adalah asap dan debu yang termasuk polusi partikel dan juga ozon, CO, dan SPM (Suspended Particulate Matter) khususnya beberapa jenis logam berat seluruhnya telah dibuktikan memberi pengaruh yang merugikan kesehatan manusia (Yusad, 2003).

Berdasarkan latar belakang diatas maka rumusan masalah yang dikaji dalam penelitian ini adalah : Seberapa besar efektivitas alat penyaring udara dengan media pelepah pisang dan zeolite dalam menurunkan kadar Karbon monoksida (CO) di udara.

\section{Bahan dan Metode penelitian}

Pencemaran udara menghasilkan udara yang memiliki kandungan karbon monoksida (CO) yang tinggi. Hal yang mengakibatkan karbon monoksida (CO) tinggi di udara yaitu asap knalpot bermotor dan cerobong asap industri yang tidak memenuhi syarat.

Salah satu cara untuk menurunkan kadar $\mathrm{CO}$ tersebut adalah dengan menggunakan penyaring udara. Saringan udara yang digunakan adalah serat pelepah pisang dan zeolit. Kedua material ini akan bekerja sama untuk membantu menurunkan kadar $\mathrm{CO}$ di udara melalui alat yang akan dirancang.

Setelah difiltrasi dengan serat pelepah pisang dan zeolit, maka $\mathrm{CO}$ dapat diturunkan sehingga aman dan mengurangi pencemaran udara. Namun, apabila tidak terjadi penurunan maka beresiko terjadi pencemaran udara.

Jenis penelitian adalah eksperimen dengan rancangan Non Randomized PretestPostest Control Design yaitu obyek yang digunakan terdiri dari 2 kelompok. Kelompok pertama merupakan unit percobaan untuk perlakuan dan kelompok kedua merupakan kelompok suatu kontrol, kemudian dicari perbedaan antara pengukuran keduanya dan perbedaan ini dianggap disebabkan oleh perlakuan.

Lokasi pengambilan sampel peneltian di Traffic Light flay Over Jln.Urip Sumuharjo Kota Makassar. Untuk pembuatan alat penyaring udara dilakukan di Workshop AKL Muhammadiyah Makassar dan pemeriksaan Karbon monoksida (CO) dilakukan di Laboratorium DPLH Propinsi Kota Makassar.

Populasi dari penelitian ini adalah semua titik atau lokasi yang menghasilkan polutan udara (CO) pada proses transportasi gas buang kendaraan yang diambil di sekitaran lampu merah di Kota Makassar dan Sampel yang digunakan dalam penelitian ini adalah 4 sampel terdiri dari 2 sampel sebelum perlakuan dan 2 sampel setelah perlakuan dengan menggunakan penyaring pelepah pisang dan zeolite.

Prosedur Eksperimen Cara pengambilan sampel karbon monoksida (CO) menggunakan alat otomatis yaitu $\mathrm{CO}$ Analyzer. Pembuatan Saringan Udara yaitu dengan menggunakan Gergaji dan palu, Kayu balok, Pipa, Sambungan pipa L, Sambungan pipa T 2 buah, Corong 2 buah, Terompet, Lem pipa, Isolasi, Gunting dan paku, Accu kering dan kabel, Kipas DC 12 Volt, Kipas DC 5 Volt, Batu zeolite, Pelepah pisang.

Cara Perakitan alat : Cara pembuatan wadah balok yaitu Balok di rangkai berbentuk 
persegi panjang, kemudian Pasang triplek, triplek di pasang di tiap-tiap sisi dan Potong sisa triplek biar terlihat rapi dan wadah pun siap di gunakan.

Proses pembuatan bahan membran selulosa yaitu Sediakan pelepah pisang yang telah dikeringkan, Blender pelepah pisang secukupnya, Kemudian disaring dan didapatkan serat, Serat ditambahkan $\mathrm{NaOH} 20$ ml dan Asam asetat $30 \mathrm{ml}$ dan Serat dikeringkan dan di dapatkan membran selulosa

Proses perakitan alat penyaring udara yaitu Masukkan membran diantara corong dan pipa, arahkan corong ke arah kipas DC pertama (Input), sambungkan pipa ke arah tabung zeolite, kemudian, pasang corong ke arah kipas DC kedua (output), siapkan Accu kering, sambungkan penjempit buaya ke Accu dan alat penyaring udara siap dicoba.

Inlet yaitu tempat masuknya udara yang mengandung karbon monoksida (CO). Membran selulosa asetat yang digunakan sebanyak 13,7 gr dan merupakan polimer sederhana, membentuk ikatan kimia yang memiliki permukaan rantai selulosa seragam dan membentuk lapisan berpori, material padatan berpori inilah yang menyerap bahan-bahan di sekelilingnya, sehingga dapat dimanfaatkan sebagai material penyerap bahan berbahaya bagi lingkungan.n

Penyerapan atau pengendapan dengan larutan zeolit sebanyak $50 \mathrm{ml}$, kecepatan kipas masukan mendorong udara lebih cepat masuk ke larutan zeolit, maka partikel kimia pencemar di serap oleh zeolite, sehingga ada aksi reaksi yang ditandai dengan zeolite mengendap partikel pengotor dan menghasilkan gelembung gas karena sifatnya sebagai dehidrasi, adsobrsi, penukar ion, katalisator dan separator. Zeolit merupakan batu berongga yang terbentuk oleh jaringan silika alumina tertrahedral tiga dimensi dan mempunyai struktur yang relatif teratur dengan rongga yang di dalamnya terisi oleh logam alkali atau alkali tanah sebagai penyeimbang muatan. Outlet merupakan tempat keluarnya udara yang telah melalu tahap penyaringan

\section{HASIL PENELITIAN}

Penelitian di lakukan pada tanggal 21 juli 2017, di 2 titik pengukuran dengan menggunakan alat $\mathrm{CO}$ Analyzer dan hasil pengukuran dapat dilihat pada tabel 1.
Tabel 1

Hasil Penurunan CO dengan menggunakan Penyaring Udara Pelepah Pisang dan Zeolite, Juli 2017

\begin{tabular}{llclll}
\hline $\mathbf{N}$ & Titik & Sebel & Sesud & Penur \\
$\mathbf{0}$ & & $\begin{array}{c}\text { u m } \\
(\mathrm{ppm})\end{array}$ & $\begin{array}{l}\text { ah } \\
(\mathrm{ppm})\end{array}$ & $\begin{array}{c}\text { unan } \\
(\mathrm{ppm})\end{array}$ & $\begin{array}{c}\text { penur } \\
\text { una } n\end{array}$
\end{tabular}

(\%)

\begin{tabular}{|c|c|c|c|c|c|}
\hline 1 & $\begin{array}{l}\text { Titik 1 ( } \\
\text { Traffic } \\
\text { light fly } \\
\text { over ) }\end{array}$ & $\begin{array}{l}60 \\
\text { ppm }\end{array}$ & $\begin{array}{l}20 \\
\text { ppm }\end{array}$ & $\begin{array}{l}40 \\
\text { ppm }\end{array}$ & 66.6 \\
\hline $\begin{array}{r}2 \\
. \quad\end{array}$ & $\begin{array}{l}\text { Titik } 2 \\
\text { (Knalpot } \\
\text { Kendara } \\
\text { an) }\end{array}$ & $\begin{array}{l}700 \\
\text { ppm }\end{array}$ & $\begin{array}{l}113 \\
\text { ppm }\end{array}$ & $\begin{array}{l}587 \\
\text { ppm }\end{array}$ & 84 \\
\hline
\end{tabular}

Tabel 2

Perbandingan Perbedaan Penurunan kadar CO dengan menggunakan Alat Penyaring Udara Pelepah Pisang dan Zeolite

NO. Pengukuran $\begin{gathered}\text { awal } \\ \text { Nonurunan }\end{gathered}$

\begin{tabular}{ccc}
\hline 1. & $60 \mathrm{ppm}$ & $40 \mathrm{ppm}$ \\
2. & $700 \mathrm{ppm}$ & $587 \mathrm{ppm}$ \\
\hline
\end{tabular}

Hasil pengukuran CO pada titik 1 yang di lakukan di traffic light fly over sebelum penyaringan adalah $60 \mathrm{ppm}$ dan mengalami penurunan $40 \mathrm{ppm}$ setelah melewati media penyaring pelepah pisang dan zeolite sehingga menjadi 20 ppm.

Pada titik 2 yang dipasang langsung di knalpot kendaraan hasil pengukuran sebelum penyaringan adalah 700 ppm, setelah melalui proses penyaringan pelepah pisang dan zeolite, CO dapat diturunkan sebanyak 587 ppm sehingga menjadi 113 ppm.

\section{PEMBAHASAN}

Dalam gas buang kendaraan bermotor terdapat berbagai komponen yang berbahaya bagi tubuh Manusia. Diantaranya gas karbon monoksida (CO). Di traffic light fly over merupakan salah satu tempat yang padat akan kendaraan hal ini menjadi salah satu sumber adanya karbon monoksida (CO) di udara. Kadar karbon monoksida ( $\mathrm{CO}$ ) yang melebihi nilai ambang batas akan membahayakan kesehatan manusia dan juga lingkungan sekitar.

Salah satu upaya menurunkan kadar karbon monoksida (CO) di udara yaitu dengan menggunakan alat penyaring udara pelepah pisang dan zeolite. Dalam penyaringan ini terdapat 2 tahap penyaringan udara yaitu dengan serat pelepah pisang sebagai penyaring partikelpartikel berbahaya dan zeolite sebagai bahan penyerap partikel-partikel berbahaya yang masih belum tersaring dalam serat pelepah pisang. Serat 
Jurnal Sulolipu : Media Komunikasi Sivitas Akademika dan Masyarakat

Vol. 19 No.12019

e-issn : 2622-6960, p-issn : 0854-624X

pelepah pisang yang digunakan sebanyak 13,7 gr sedangkan batu zeolite aktif yang digunakan sebanyak 100 gr. Sampel karbon monoksida (CO) yang diukur di inlet kemudian difiltrasi dengan penyaring serat pelepah dan batu zeolite dengan menggunakan waktu retensi (lama alat bekerja) tertentu.

Transportasi menghasilkan $\mathrm{CO}$ paling banyak diantara sumber-sumber CO lainnya, terutama dari kendaraan-kendaraan yang menggunakan bensin sebagai bahan bakar. Karbon monoksida (CO), dihasilkan dari pembakaran yang tidak sempurna dari bahan bakar yang mengandung karbon dan oleh pembakaran pada tekanan dan suhu tinggi yang terjadi pada mesin. Karbon monoksida (CO) dapat juga dihasilkan dari reaksi oksidasi gas metana oleh radikal hidroksi dan dari perombakan/pembusukan tanaman meskipun tidak sebesar yang dihasilkan oleh bensin (Farziaz, 1992).

Transportasi yang diukur dalam penelitian ini yaitu motor yang bermerek Rxking yamaha tahun 2007, akibat penggunaan mesin yang cukup lama maka pada pengukuran ini emisi $\mathrm{CO}$ yang di hasilkan sangat tinggi yaitu berkisar 700 ppm. Pada jam-jam sibuk di daerah perkotaan konsentrasi gas CO bisa mencapai 50 - 100 ppm. Tingkat kandungan $\mathrm{CO}$ di atmosfir berkorelasi positif dengan padatnya lalu lintas, tetapi korelasi negatif dengan kecepatan angin. Keberadaan atau umur gas $\mathrm{CO}$ di atmosfir tidak lama hanya kira-kira 4 bulan. Hal ini terjadi karena karbon monoksida di atmosfir dihilangkan melalui reaksi dengan radikal hidroksil, HO* (Farziaz, 1992).

Pada pengukuran di titik 1 traffic light fly over kota makassar pengukuran gas $\mathrm{CO}$ yang dihasilkan konsentrasinya 60 ppm. Penelitian ini dilakukan pada jam-jam sibuk yaitu jam pulang kerja sekitar jam 3 sore. Gas karbon Monoksida (CO) merupakan Parameter pencemaran udara yang sangat perlu diperhatikan karena merupakan polutan yang sangat berbahaya dari kendaraan bermotor, tentunya dapat mengganggu kesehatan manusia. Kendaraan Bermotor merupakan sumber utama CO terutama pada kendaraan yang sudah tua, karena mesin kendaraan kurang berfungsi secara baik (Basuki,2008 dalam Ayusti Dirga, 2014 ).

Penyaring Membran Selulosa Asetat dan zeolite Membran Selulosa Asetat sebagai Pemisahan Partikulat Membran berfungsi memisahkan material berdasarkan ukuran dan bentuk molekul, menahan komponen dari umpan yang mempunyai ukuran lebih besar dari pori-pori membran dan melewatkan komponen yang mempunyai ukuran yang lebih kecil. Filtrasi dengan menggunakan membran selain berfungsi sebagai sarana pemisahan juga berfungsi sebagai sarana pemekatan dan pemurnian dari suatu larutan yang dilewatkan pada membran tersebut. Menurut Dutre dan G. Tragardh tahun 1995 membran dapat memisahkan antara dua atau lebih tipe molekul berdasarkan ukuran molekul, bentuk, susunan kimia atau berdasarkan energi potensialnya. Membran dapat diaplikasikan secara luas dalam berbagai proses pemisahan. Proses pemisahan dapat menggunakan membran, antara lain membran mikrofiltrasi, ultrafiltrasi, nanofiltrasi, dan reverse osmosis (Ina Ade Winani, 2011)

Membran mikrofiltrasi berfungsi untuk merejeksi partikel dari air yang berukuran 0,1-100 $\mu \mathrm{m}$. Ultrafiltrasi merupakan pemisahan partikel berukuran nano. Membran ultrafiltrasi untuk merejeksi partikel dari air yang berukuran $5 \mathrm{~nm}$ sampai 0,1 $\mu \mathrm{m}$. Nanofiltrasi dan Reverse osmosis juga mampu memisahkan partikel berukurannano, ukuran partikel yang dapat direjeksi sekitar < 5 $\mu \mathrm{m}$. Selain itu proses-proses tersebut dapat dibedakan dalam hal kisaran tekanan operasinya. Mikrofiltrasi beroperasi pada tekanan antara 0,1-2 Bar. Ultrasfiltrasi beroperasi pada tekanan antara 1-5 Bar. Nanofiltrasi beroperasi pada tekanan antara 5-20 Bar. Sedangkan RO beroperasi pada tekanan antara 10-100 Bar (Notodarmojo, S.Maya Santhy, Zulkarnain,T.,2004 dalam Ina Ade Winani 2011).

Selulosa asetat (CA) merupakan ester organik selulosa yang berupa padatan putih, tidak berbau, dan tidak berasa, dihasilkan melalui esterifikasi molekul selulosa dengan anhidrida asetat dan sejumlah katalis. Selain asam sulfat, dalam pembentukan CA dapat digunakan katalis asam perklorat dan zink klorida. Selulosa memiliki tiga gugus hidroksil per residu anhidroglukosa, sehingga dapat dibentuk menjadi selulosa monoasetat, diasetat, atau triasetat. CA yang homogen hanya diperoleh dari substitusi sempurna gugus-gugus hidroksil anhidroglukosa menjadi selulosa triasetat (Karim, M.A, 2010 dalam Ina Ade Winani 2011)

Gutman tahun 1987 mendefinisikan filtrasi sebagai pemisahan material partikulat dalam suatu campuran dengan cara mengalirkan umpan melalui suatu membran yang dapat menahan partikulat yang memiliki molekul lebih besar dari ukuran pori membran. Menurut Wenten tahun 1999 ada dua kelas utama dalam proses filtrasi, yaitu filtrasi partikel konvensional dan proses filtrasi membran. Filtrasi konvensional biasanya dilakukan dalam pemisahan partikel besar yang tersuspensi dengan ukuran lebih dari $10 \mu \mathrm{m}$. Sedangkan filtrasi membran memisahkan zat dengan ukuran molekul kurang dari $10 \mu \mathrm{m}$.

Dalam penelitian ini serat membran selulosa asetat didapatkan dari semua jenis pelepah pohon pisang. serat pelepah pisang yang di jadikan filter adalah serat yang sudah dikeringkan dan telah diaktivasi terlebih dahulu dengan menggunkan 
Jurnal Sulolipu : Media Komunikasi Sivitas Akademika dan Masyarakat

Vol. 19 No.1 2019

e-issn : 2622-6960, p-issn : 0854-624X

larutan $\mathrm{NAOH}$ dan Asam Asetat. Membran selulosa asetat yang digunakan dalam penelitian ini sebanyak $13,7 \mathrm{gr}$, membran selulosa ini merupakan polimer sederhana, yang membentuk ikatan kimia dan memiliki permukaan rantai selulosa seragam dan membentuk lapisan berpori, material padatan berpori inilah yang menyerap bahan- bahan di sekelilingnya, sehingga dapat di manfaatkan sebagai material penyerap bahan berbahaya seperti Gas CO di lingkungan.

Hasil penelitian sebelumnya oleh Meitri Widya Pangestika membuat inovasi dengan memanfaatkan pelepah dan tangkai daun pisang sebagai penyaring udara kotor penuh karbon monoksida (CO). Dari hasil penelitian tersebut pelepah yang dikeringkan dan diproses karbonasi hasilnya di buat jadi filter, apabila di pasang dimotor, dia bisa menyaring karbon monooksida hingga $76 \%$, dan apabila dibuat masker efek filtrasinya $94 \%$ (Meitri Widya, 2014).

Zeolite mempunyai kapasitas yang tinggi sebagai penyerap (adsorben). Mekanisme adsorpsi yang mungkin terjadi adalah adsorpsi fisika (melibatkan gaya van der walls), adsorpsi kimia (melibatkan gaya elektrostatik), ikatan hidrogen dan pembentukan kompleks koordinasi(Supraptiningsih, 2011). Molekul atau zat yang diserap akan menempati posisi pori. Daya serap (adsorpsi) zeolit tergantung dari jumlah pori dan luas permukaan. Molekul-molekul dengan ukuran lebih kecil dari pori yang mampu terserap oleh zeolit.

Daya serap yang dihasilkan dari zeolit dapat dimanfaatkan untuk menyaring udara yang masuk ke ruang bakar dan diharapkan dapat mengurangi kadar nitrogen serta unsur-unsur lain yang masuk ke dalam ruang bakar sehingga konsentrasi panas yang ada pada ruang bakar dapat lebih maksimum untuk menguraikan oksigen dan bahan bakar. Keberadaan unsur selain oksigen menggangu proses pembakaran karena panas hasil kompresi juga diambil oleh unsur pengganggu (N2, H2O dll.). Akibatnya, oksigen dan bahan bakar menerima panas lebih kecil, dengan demikian gas yang dihasilkan ( $\mathrm{CO} 2$ dan $\mathrm{H} 2 \mathrm{O}$ ) juga semakin kecil (Wardono, H. 2004).

Hasil penemuan McBain pada tahun 1931 yang melakukan uji coba pemanasan dengan aktivasi mineral zeolit membuktikan bahwa zeolit mampu menyerap molekul- molekul gas dengan ukuran partikel tertentu. Zeolite yang digunakan dalam penelitian ini merupakan batu berongga yang terbentuk oleh jaringan silika alumina tetraherdral tiga dimensi dan mempunyai struktur yang relatif teratur dengan rongga yang di dalamnya terisi oleh logam alkali atau alkali tanah sebagai penyeimbang muatan.

Banyak zeolite yang digunakan dalam penelitian ini yaitu 100 gram yang telah diaktivasi terlebih dahulu.kecepatan kipas yang masuk mendorong udara melewati zeolite, mengakibatkan partikel kimia pencemar diserap oleh zeolite, sehingga ada aksi reaksi yang di tandai dengan zeolite mengendap partikel pengotor dan menghasilkan gelembung gas karena sifatnya sebagai dehirasi, adsorbsi, penukar ion katalisator dan separator.

Perbedaan hasil pengukuran ini di karenakan pengukuran yang dilakukan pada dititik 1 telah bercampur dengan udara ambien sehingga kadar CO yang diperoleh berkurang sedangkan pengukuran yang dilakukan pada titik 2 diukur langsung pada knalpot kendaraan bermotor sehingga hasil pengukuran $\mathrm{CO}$ yang diperoleh sangat tinggi dan penurunan yang terjadi cukup besar.

Penyebab gas karbon monoksida (CO) terlalu tinggi pada knalpot kendaraan yang diteliti dikarenakan tehnik menggunakan karburator misalkan penyetelan campuran terlalu tinggi, tingginya volume bensin yang digunakan, jet bahan bakar terlalu besar, dan filter udara yang tersumbat (Kotor). Sehingga terjadilah pembakaran tidak sempurna pada knalpot kendaraan tersebut yang menghasilkan hasil pengukuran pada titik 2 ini sangat tinggi dan usia kendaraan bermotor yang digunakan dalam pengukuran sudah cukup lama. Berbeda halnya dengan pengukuran gas karbon monoksida (CO) yang didapatkan pada titik 1 cukup rendah dibandingkan titik 2 , dikarenakan gas karbon monoksida (CO) hasil pengukuran tersebut telah bercampur dengan partikel-partikel selain gas $\mathrm{CO}$ yang di sebabkan oleh angin yang kencang pada lokasi pengukuran (Anonim, 2016)

Hasil percobaan penelitian ini menunjukkan adanya penurunan kadar karbon monoksida (CO) dengan presentase penurunan hingga $66.6 \%$ pada titik 1 dan $84 \%$ pada titik 2 . Hal ini menandakan kedua media ini bekerja sesuai fungsinya dengan baik.

\section{KESIMPULAN}

Kadar karbon monoksida (CO) sebelum melalui media penyaring pelepah pisang dan zeolite adalah $60 \mathrm{ppm}$ pada titik pertama dan 700 ppm pada titik kedua. Hasil penurunan kadar $\mathrm{CO}$ dengan menggunakan alat penyaring udara pelapah pisang dan zeolite adalah 66,6 \% pada titik 1 dan $84 \%$ pada titik 2. Hal yang menyebabkan terjadinya perbedaan di kedua titik ini adalah objek penempatan alat yang berbeda, pada titik 1 pengukuran dilakukan jauh dari sumber CO (kendaraan) dan pada titik 2 pengukuran dilakukan langsung di knalpot kendaraan bermotor.

\section{SARAN}

Penelitian selanjutnya perlu dilakukan di ruang parkiran basement yang sekarang telah ditemukan di perkantoran, toko-toko besar, rumah 
Jurnal Sulolipu : Media Komunikasi Sivitas Akademika dan Masyarakat

Vol. 19 No.12019

e-issn : 2622-6960, p-issn : 0854-624X

sakit dan lain sebagainya, sehingga kadar $\mathrm{CO}$ yang di hasilkan cukup tinggi. Mengingat banyak bahan yang dapat dijadikan sebagai filter udara, maka perlu dilakukan penelitian dengan media yang berbeda yang mungkin lebih efektif dan efisien. Selain itu perbedaan waktu kontak, banyak media yang digunakan harus diperhatikan keefektifannya.

\section{DAFTAR PUSTAKA}

Airo Ardiando Baroto. 2008. Perancangan Cigarette Smoke. http:/lip.ui.ac.id/file.PDF. Diakses 19 Mei 2017.

Buku kualitas Udara, 2013. Laporan Pemantaun kualitas Udara. http://slh.bantulkab.go.id.PDF. Diakes 16 Mei 2017

Bagus Prihantoro, 2015. Kisah meitri : bagaikan isaac Newton, ciptakan filter pelepah pisang. News.detik.com. diakses 7 juni 2017

Bumi Lestari. 2008. Dampak Bising dan Kualitas Udara pada Lingkungan Denpassar. http:/ojs.anud.ac.id/blje/article/download.PDF. Diakes 22 Mei 2017.

Depkes, 2007. Parameter Pencemar Udara dan Dampaknya Terhadap Kesehatan. http:/www.depkes.go.id/download/udara.PDF. Diakses 23 Mei 2017

Infodatin Kemenkes RI, 2015. Masalah Kesehatan Akibat Kabut Asap Kebakaran Hutan dan Lahan. www.depkes.go.id/infodatin-asap.PDF. Diakses 21 Mei 2017.

Ina Ade Winani, 2011. Kajian Efektivitas Membran Selulosa asetat pada proses Fiktrasi Bertahap untuk desalinasi Air Laut. ppjp.unlam.ac.id/journal/index.php/konversi/article/download/2994/2557. Diakses 24 juli 2017.

Keputusan Mentri Kesehatan Republik Indonesi Nomor 1407 Tahun 2002. Tentang Pedoman pengendalian dampak pencemaran udara.

Mukono H.J, 2008. Pencemaran Udara dan Pengaruhnya terhadap Gangguan Pernapasan. Surabaya : Airlangga University Press.

Muhammad Ikwan. 2011. Studi kepadatan kendaraan Bermotor dan kandungan Karbon Monoksida (CO) pada udara di dua TrafficLight Jalan Hertasning kota Makassar (KTI tdak Diterbitkan). Kementrian Kesehatan Republik Indonesia, Politeknik Kesehatan Makassar, Jurusan Kesehatan Lingkungan.

M.Ali Akbar, 2010. Pembuatan Membran Mikrofilter Zeolit Alam dengan Penambahan Semen Portland Putih. repository.uinjkt.ac.id/dspace/bitstream/123456789/.../M.ALI\%20AKBARFST.pdf. Diakses 7 juni 2017

Peraturan Pemerintah Republik Indonesia No.41 Tahun 1999. Tentang Pengandalian Pencemaran Udara. Jakarta, 1999.

Putra, 2011. pencemaran-udara-dampak-dan-solusinya. http://putracenter.net. Diakses 16 Mei 2017

Srikandi Fardiaz, 1992. Polusi Air dan Udara. Yogyakarta : Penerbit Kanisus Syamsul Bahri, 2015. Pembuatan Pulp dari Batang Pisang. http:/Ft.unimal.ic.id/teknikkimia/jurnal. Diakses 15 Mei 2017.

Siti Kholifah, 2016. Zeolit Alam Sebagai Adsorben ion Logam aluminium dam air Kolam Renanguny dengan Metode adsorbsi Kola.Eprints.uny.ac.id./41237/1Skripsi.pdf. Diakses 24 juli 2017.

Tatyalfiah , 2007. Udara Ambien. https://tatyalfiah.files.wordpress.com. Diakes 18 Mei 2017.

Uli febriarn, 2016. Penelitian terbaru : penyejuk udara dari batang pisang.m.harianjōgja.com. diakses 7 juni 2017 